\title{
Hydrogenobacter thermophilus gen. nov., sp. nov., an Extremely Thermophilic, Aerobic, Hydrogen-Oxidizing Bacterium
}

\author{
TOSHIYUKI KAWASUMI, YASUO IGARASHI, TOHRU KODAMA, * AND YASUJI MINODA \\ Department of Agricultural Chemistry, University of Tokyo, Bunkyo-ku, Tokyo 113, Japan
}

\begin{abstract}
Six strains of strictly thermophilic, obligately chemolithotrophic, hydrogen-oxidizing bacteria were isolated from hot springs located in Izu and Kyushu, Japan. The bacterial strains which we tested were gram negative, nonmotile, nonsporeforming, long, straight, and rod shaped. The cell size was 0.3 to 0.5 by 2.0 to $3.0 \mu \mathrm{m}$. The deoxyribonucleic acid guanine-plus-cytosine contents of the six strains were between 43.5 and $43.9 \mathrm{~mol} \%$. The optimal temperature for autotrophic growth on $\mathrm{H}_{2}-\mathrm{O}_{2}-\mathrm{CO}_{2}$ was between 70 and $75^{\circ} \mathrm{C}$. None of the strains grew at 37 or $80^{\circ} \mathrm{C}$. The neutral $\mathrm{pH}$ range was suitable for growth. No strain showed heterotrophic growth at the expense of 48 organic compounds or on complex media, in contrast to all other known aerobic hydrogen-oxidizing bacteria which are facultative autotrophs. The major cellular fatty acids were a straight-chain saturated $C_{18: 0}$ acid and a straight-chain unsaturated $C_{20: 1}$ acid with one double bond. $\mathrm{C}_{16: 0}$ and $\mathrm{C}_{18: 1}$ fatty acids and $\mathrm{C}_{21: 0}$ cyclopropane acid were minor components. Cytochromes $b$ and $c$ were found in all of the strains. The polyacrylamide gel electrophoretic patterns of the total soluble proteins of all of the strains were essentially the same. The name Hydrogenobacter thermophilus gen. nov., sp. nov., is proposed for the six new isolates, and type strain TK-6 has been deposited with the culture collection of the Institute of Applied Microbiology, University of Tokyo, as strain IAM 12695.
\end{abstract}

Five species of aerobic, thermophilic, hydrogen-oxidizing bacteria have been described previously. These are Hydrogenomonas thermophilus (21), Pseudomonas thermophila K-2 (13), Pseudomonas hydrogenothermophila (14), Flavobacterium autothermophilum (14), and Bacillus schlegelii (2, 24). These organisms are all aerobic, facultative chemolithotrophs. Methanobacterium thermoautotrophicum (29) is thermophilic, obligately chemolithoautotrophic, and hydrogen oxidizing but is strictly anaerobic and methane producing. The aerobic, hydrogen-oxidizing bacteria (both mesophiles and thermophiles) are all facultative lithoautotrophs that are capable of growing heterotrophically on various kinds of organic compounds. Therefore, the hydrogen-oxidizing bacteria are assumed to form a physiological group containing no obligate chemolithoautotrophs, in contrast to other chemolithoautotrophic bacterial groups.

In this paper we describe the phenotypic and chemotaxonomic characteristics of six newly isolated strains of aerobic, thermophilic, hydrogen-oxidizing bacteria which are obligate chemolithoautotrophs.

\section{MATERIALS AND METHODS}

Isolation of bacteria. The isolation procedure which we used has been described previously (18). Water and soil samples were collected from hot springs in Izu and Kyushu, Japan.

Bacterial strains isolated. Strains TK-6 ${ }^{\mathrm{T}}(\mathrm{T}=$ type strain $)$, TK-38, TK-120, TK-F, TK-G, and TK-H were isolated and investigated in this study.

Culture medium and cultivation of bacteria. The basal medium had the same composition and $\mathrm{pH}(7.2)$ as the isolation medium described previously (18), except that it contained $1.0 \mathrm{~g}$ of $\mathrm{NaCl}$ per liter. The bacteria were grown on a reciprocating shaker at $70^{\circ} \mathrm{C}$ for about $12 \mathrm{~h}$ in $40-\mathrm{ml} \mathrm{L}$ tubes and $500-\mathrm{ml}$ shaking flasks containing 9.5 and $50 \mathrm{ml}$ of liquid medium, respectively, and a gas mixture consisting of $\mathrm{H}_{2}, \mathrm{O}_{2}$, and $\mathrm{CO}_{2}(75: 15: 10)$. A 2-liter jar fermentor (Labotec Co.) operated with a working volume of 1 liter was also used

* Corresponding author. to culture bacteria. About $300 \mathrm{ml}$ of a $12-\mathrm{h}$ preculture was used as the inoculum for the jar fermentor. The gas mixture for the fermentor $\left(\mathrm{H}_{2}\right.$-air- $\left.\mathrm{CO}_{2}, 390: 150: 60\right)$ was prepared by using thermal mass flow meters (Ueshima Seisakusho Ltd.) for $\mathrm{H}_{2}$ and $\mathrm{CO}_{2}$ and a flow meter for air. The flow rate was adjusted to $600 \mathrm{ml} / \mathrm{min}$, and the $\mathrm{pH}$ was held at 7.2 with ammonium hydroxide. Bacterial growth was measured turbidimetrically at $540 \mathrm{~nm}$ with a Spectronic 20 colorimeter (Bausch \& Lomb, Inc.).

Phenotypic characterization. Cell form, Gram reaction, motility, and spore formation were determined with cells grown autotrophically in shaking flasks. Gram staining was carried out by the Hucker modification (11), using cells in the early exponential, middle exponential, and stationary growth phases. Motility was determined in hanging drops by using cells grown at 50 and $70^{\circ} \mathrm{C}$. Spore formation was tested by the method of Dorner (12). The maximum and optimum temperatures for bacterial growth were determined in jar fermentor cultures. Growth at $37^{\circ} \mathrm{C}$ was tested in shaking flasks for 4 weeks. The utilization of compounds as sole nitrogen sources was tested by using basal liquid medium without $\mathrm{NH}_{4} \mathrm{NO}_{3}$ that was supplemented with one of the nitrogen compounds being examined. The amounts of nitrogen added corresponded to $1 \mathrm{~g}$ of $\mathrm{NH}_{4} \mathrm{NO}_{3}$ per liter. Growth on organic compounds was tested by using liquid basal medium and solid basal medium solidified with $1.5 \%$ BactoAgar (Difco Laboratories); these basal media contained the various organic compounds tested at concentrations of $0.1 \%$ (wt/vol) and were incubated for more than 2 weeks under air at 50 and $70^{\circ} \mathrm{C}$. The presence of peroxidase was determined by the procedure of Thomas et al. (26).

DNA base composition. The deoxyribonucleic acid (DNA) was extracted by the method of Saito and Miura (23), and the DNA base composition was calculated from the thermal denaturation temperature (20). Calf thymus DNA $(42.0$ mol\% guanine plus cytosine) was used as the reference DNA.

Cellular fatty acid composition. Cells cultivated autotrophically at $70^{\circ} \mathrm{C}$ in the jar fermentor were used to analyze the cellular fatty acids. Fatty acid methyl esters were liberated 
from $40 \mathrm{mg}$ of lyophilized cells by methanolysis at $100^{\circ} \mathrm{C}$ for $3 \mathrm{~h}$ with $3 \mathrm{ml}$ of $5 \%$ anhydrous methanolic $\mathrm{HCl}$ and were extracted three times with 3-ml volumes of petroleum ether. A Shimadzu model GC-6A gas chromatograph equipped with a glass column ( $3 \mathrm{~mm}$ by $2 \mathrm{~m}$ ) packed with $10 \%$ diethyleneglycol succinate and $2 \% \mathrm{OV}-1$ on Chromosorb $\mathrm{W}$ (80/100 mesh) was used to separate the fatty acid methyl esters. Gas-liquid chromatography-mass spectrometry with a Shimadzu model LKB 9000 instrument was used to identify each fatty acid. The positions of the double bonds in the $\mathrm{C}_{20: 1}$ and $\mathrm{C}_{18: 1}$ acids were determined by mass spectra of their pyrrolidides (1).

Cytochrome systems. Jar fermentor-cultured cells suspended in $0.05 \mathrm{M}$ phosphate buffer ( $\mathrm{pH} 7.0$ ) were passed through a French pressure cell (American Instrument Co.). The intact cells and debris were removed by centrifugation at $10,000 \times g$ for $20 \mathrm{~min}$, and the cell-free extracts were used to investigate the cytochrome systems. Cytochrome spectra at room temperature were recorded with a Hitachi model 20010 spectrophotometer by using cuvettes having a $1-\mathrm{cm}$ light path. The cytochromes were identified from the $\alpha$ peaks in their reduced-minus-oxidized difference spectra, which were obtained by the dithionite-ascorbic acid- $\mathrm{H}_{2} \mathrm{O}_{2}$ method (3).

Electrophoresis of cell proteins. Cell-free extracts prepared by the procedure described above were used for gel electrophoresis of bacterial proteins. Slab gels containing $7.5 \%$ polyacrylamide were prepared by the method of Davis (9). Both the upper and lower reservoirs of the electrophoresis apparatus were filled with buffer containing $6 \mathrm{~g}$ of tris(hydroxymethyl)aminomethane, $28.8 \mathrm{~g}$ of glycine, and $1,000 \mathrm{ml}$ of distilled water $(\mathrm{pH} 8.3)$. Electrophoresis was carried out at $5^{\circ} \mathrm{C}$ for about $12 \mathrm{~h}$ at a constant current of $10 \mathrm{~mA}$. The total cell proteins were stained by using a solution containing $50 \mathrm{mg}$ of Coomassie brilliant blue $\mathrm{R}, 100 \mathrm{ml}$ of methyl alcohol, and $20 \mathrm{ml}$ of acetic acid in a total volume of $200 \mathrm{ml}$ (adjusted by adding distilled water). The stained gel was decolorized with a solution containing $250 \mathrm{ml}$ of methyl alcohol and $70 \mathrm{ml}$ of acetic acid in a total volume of $1,000 \mathrm{ml}$ (adjusted by adding distilled water). Malate dehydrogenase was visualized with a reaction mixture containing $0.5 \mathrm{~g}$ of $\mathrm{L}$ malic acid (disodium salt), $50 \mathrm{mg}$ of nicotinamide adenine dinucleotide, $20 \mathrm{mg}$ of Nitro Blue Tetrazolium and $5 \mathrm{mg}$ of phenazine methosulfate in $100 \mathrm{ml}$ of $0.05 \mathrm{M}$ tris(hydroxymethyl)aminomethane hydrochloride buffer ( $\mathrm{pH} 7.4)$ at $37^{\circ} \mathrm{C}$ (25). Isocitrate dehydrogenase was visualized with a reaction mixture containing $250 \mathrm{mg}$ of DL-isocitric acid (trisodium salt), $50 \mathrm{mg}$ of nicotinamide adenine dinucleotide, $20 \mathrm{mg}$ of Nitro Blue Tetrazolium, and $4 \mathrm{mg}$ of phenazine methosulfate in $100 \mathrm{ml}$ of $0.05 \mathrm{M}$ tris(hydroxymethyl)aminomethane hydrochloride buffer ( $\mathrm{pH} \mathrm{7.4)}$ at $37^{\circ} \mathrm{C}(25)$. Glucose-6-phosphate isomerase was visualized with a reaction mixture containing $80 \mathrm{mg}$ of fructose 6-phosphate (disodium salt), 20 mg of nicotinamide adenine dinucleotide phosphate, $20 \mathrm{mg}$ of Nitro Blue Tetrazolium, $4 \mathrm{mg}$ of phenazine methosulfate, $40 \mathrm{mg}$ of $\mathrm{MgCl}_{2}$, and $<80 \mathrm{U}$ of glucose-6-phosphate dehydrogenase in $100 \mathrm{ml}$ of $0.05 \mathrm{M}$ tris(hydroxymethyl)aminomethane hydrochloride buffer $\left(\mathrm{pH} \mathrm{7.4)}\right.$ at $37^{\circ} \mathrm{C}$ (25). Each enzyme reaction was stopped with $7 \%$ acetic acid.

\section{RESULTS}

Phenotypic and cultural characteristics. The strains were all isolated from soil samples from environmental settings with temperatures above $45^{\circ} \mathrm{C}$. The isolation procedure used has been described in detail previously (18). The dilution method was used because no bacterial colonies developed on plates under either autotrophic or heterotrophic conditions after repeated enrichment culturing. The morphological features of the six strains isolated are listed in Table 1. The strains were gram negative throughout all growth phases. No cell motility was observed in hanging drops at 50 or $70^{\circ} \mathrm{C}$, and electron microscopic observations showed no flagella. Spore formation was not observed, as is usual with gram-negative bacteria. No filamentous bacterial form like that of Thermus aquaticus (6) or Methanobacterium thermoautotrophicum (30) was observed regardless of the growth temperature or phase. Organelles like mesosomes were observed in electron micrographs of ultrathin sections of strain TK $-6^{\mathrm{T}}$ grown autotrophically in a jar fermentor, but the physiological function of these organelles is not known (Fig. 1). Intracytoplasmic membrane structures like those present in methylotrophs and nitrifying bacteria were observed. The optimum growth temperature was between 70 and $75^{\circ} \mathrm{C}$ (Fig. 2). No growth was observed at 37 or $80^{\circ} \mathrm{C}$. The specific growth rates under autotrophic conditions at the optimum temperature were $0.33,0.34,0.33,0.35,0.42$, and 0.36 for strains TK- $6^{\mathrm{T}}$, TK-38, TK-120, TK-F, TK-G, and TK-H, respectively. No growth factors were required, and a neutral $\mathrm{pH}$ was suitable for growth. Ammonium and nitrate ions were utilized as nitrogen sources, but urea and gaseous nitrogen were not. Nitrite inhibited growth. Nitrate reduction was positive, peroxidase was positive, and urease was negative in the case of strain TK- $6^{\mathrm{T}}$. Membrane-bound hydrogenase activity was observed in cell-free extracts of strain TK- $6^{\mathrm{T}}$, but nicotinamide adenine dinucleotide-dependent soluble hydrogenase activity was not. The strains could utilize none of the following organic compounds and media as sole sources of energy and carbon: glucose, fructose, galactose, maltose, sucrose, xylose, raffinose, L-rhamnose, D-mannose, D-trehalose, mannitol, starch, formate, acetate, propionate, pyruvate, succinate, malate, citrate, fumarate, maleate, glycolate, gluconate, DL-lactate, $\alpha$-ketoglutarate, $p$ hydroxybenzoate, DL- $\beta$-hydroxybutyrate, betaine, methanol, ethanol, methylamine, dimethylamine, trimethylamine, glycine, L-glutamate, L-aspartate, L-serine, L-leucine, L-

TABLE 1. Characteristics of $\boldsymbol{H}$. thermophilus strains

\begin{tabular}{|c|c|c|c|c|c|c|c|c|c|c|c|}
\hline \multirow{2}{*}{ Strain } & \multirow{2}{*}{ Cell shape } & \multicolumn{2}{|c|}{$\begin{array}{l}\text { Cell dimensions } \\
\qquad(\mu \mathrm{m})\end{array}$} & \multirow{2}{*}{$\begin{array}{l}\text { Gram } \\
\text { reaction }\end{array}$} & \multirow{2}{*}{$\begin{array}{l}\text { Mo- } \\
\text { tility }\end{array}$} & \multirow{2}{*}{$\begin{array}{l}\text { Guanine- } \\
\text { plus- } \\
\text { cytosine } \\
\text { content } \\
\text { (mol\%) }\end{array}$} & \multicolumn{2}{|c|}{$\begin{array}{l}\text { Growth temp } \\
\left({ }^{\circ} \mathrm{C}\right)\end{array}$} & \multirow{2}{*}{$\begin{array}{l}\text { Growth } \\
\text { factor } \\
\text { require- } \\
\text { ment }\end{array}$} & \multirow{2}{*}{$\begin{array}{l}\text { Energy } \\
\text { source }\end{array}$} & \multirow{2}{*}{$\begin{array}{l}\text { Source area } \\
\text { (hot springs) }\end{array}$} \\
\hline & & Width & Length & & & & $\begin{array}{l}\text { Opti- } \\
\text { mum }\end{array}$ & $\begin{array}{l}\text { Maxi- } \\
\text { mum }\end{array}$ & & & \\
\hline TK-6 & Long straight rods & $0.3-0.5$ & $2.0-3.0$ & - & - & 43.7 & $70-75$ & $<80$ & - & $\mathrm{H}_{2}$ & Mine, Izu \\
\hline $\mathrm{TK}-38$ & Long straight rods & $0.3-0.5$ & $2.0-3.0$ & - & - & 43.5 & $70-75$ & $<80$ & - & $\mathrm{H}_{2}$ & Atagawa, Izu \\
\hline TK-120 & Long straight rods & $0.3-0.5$ & $2.0-3.0$ & - & - & 43.7 & $70-75$ & $<80$ & - & $\mathrm{H}_{2}$ & Shimogamo, Izu \\
\hline TK-F & Long straight rods & $0.4-0.5$ & $2.5-3.0$ & - & - & 43.7 & $70-75$ & $<80$ & - & $\mathrm{H}_{2}$ & Yufuin, Kyushu \\
\hline TK-G & Long straight rods & $0.4-0.5$ & $2.5-3.0$ & - & - & 43.9 & $70-75$ & $<80$ & - & $\mathrm{H}_{2}$ & Yufuin, Kyushu \\
\hline TK-H & Long straight rods & $0.4-0.5$ & $2.5-3.0$ & - & - & 43.7 & $70-75$ & $<80$ & - & $\mathrm{H}_{2}$ & Kan-nawa, Kyushu \\
\hline
\end{tabular}




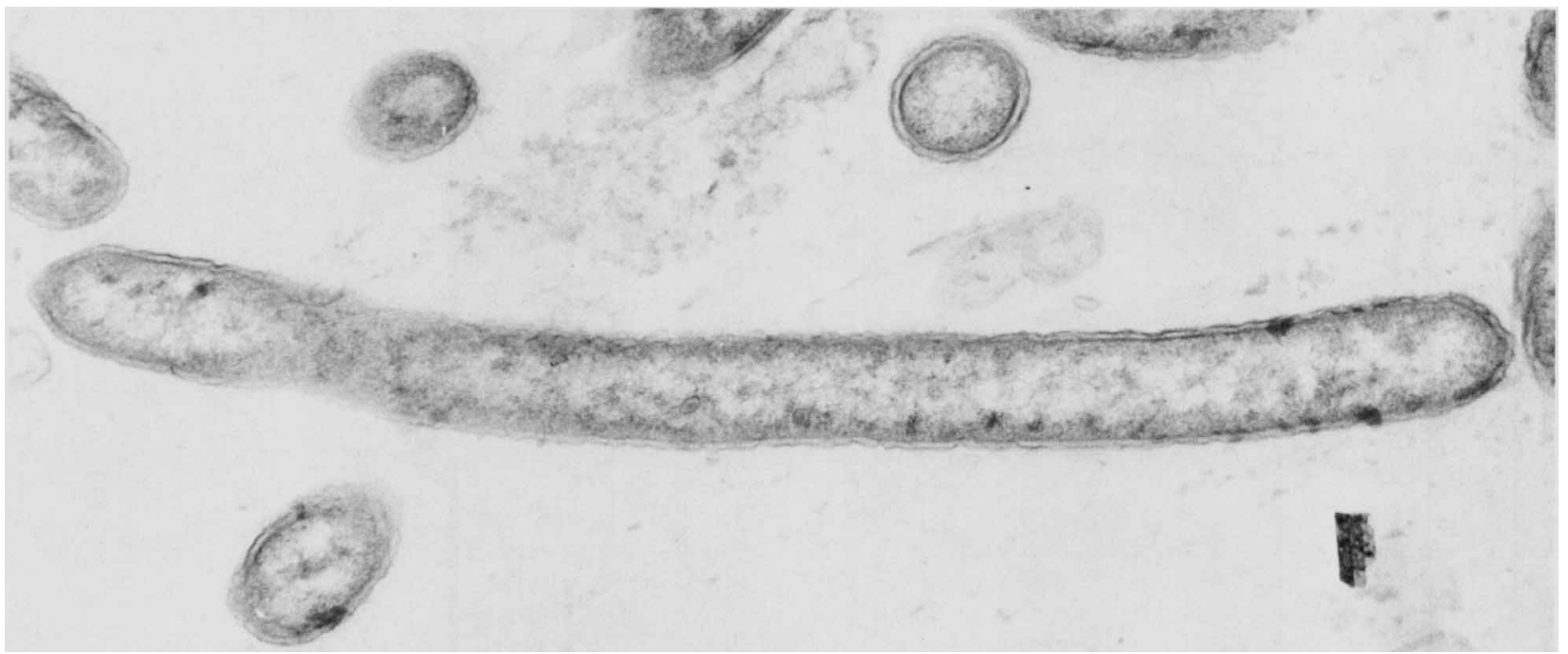

FIG. 1. Electron micrograph of ultrathin section of $H$. thermophilus strain TK- $6^{\mathrm{T}}$.

valine, L-tryptophan, L-histidine, L-alanine, L-lysine, L-proline, L-arginine, nutrient broth, yeast extract-malt extract medium, and brain heart infusion. The strains showed no growth under an atmosphere containing $90 \% \mathrm{CO}, 5 \% \mathrm{CO}_{2}$, and $5 \% \mathrm{O}_{2}$. The effects of organic compounds at different concentrations $(0.02,0.05$, and $0.1 \% \mathrm{wt} / \mathrm{vol})$ on the growth of strain TK $-6^{\mathrm{T}}$ were examined for glucose, fructose, pyruvate, citrate, $\alpha$-ketoglutarate, succinate, fumarate, malate, acetate, and ethanol with and without yeast extract or carbon dioxide. In all these cases, no heterotrophic growth was observed.

DNA base composition. The DNA base compositions of the six strains ranged from 43.5 to 43.9 mol\% guanine plus cytosine (Table 1). These values are much lower than the values for all gram-negative hydrogen-oxidizing bacteria reported previously.

Cellular fatty acid composition. The main fatty acids of all of the strains were a stright-chain saturated $\mathrm{C}_{18: 0}$ acid and a straight-chain unsaturated $\mathrm{C}_{20: 1}$ acid with one double bond ( $\Delta 11)$ (Fig. 3). The $C_{20: 1}$ acid was identified by its retention time, by the disappearance of its gas chromatogram peaks

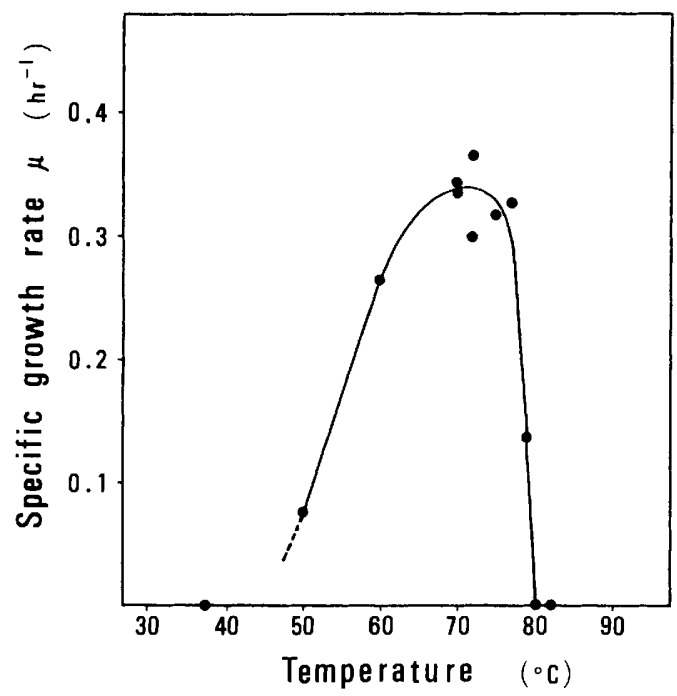

FIG. 2. Effect of temperature on cell growth of strain TK- $6^{\mathrm{T}}$.
(DEGS and OV-1 columns) after saturation of its double bond by using palladium black catalyst and hydrogen gas, and by mass spectrum data. These two fatty acids comprised about $80 \%$ of the total cellular fatty acids of the strains. The other minor fatty acids identified (less than $10 \%$ of the total acids) were $\mathrm{C}_{16: 0}, \mathrm{C}_{16: 1}, \mathrm{C}_{18: 1}(\Delta 9)$, and 3-OH $\mathrm{C}_{14: 0}$ acids. The 3-OH C $\mathrm{C}_{14: 0}$ acid was identified by its retention times on polar (DEGS) and nonpolar (OV-1) gas chromatographic columns, by its $R_{f}$ value on silica gel thin-layer chromatography plates (Silica Gel $60 \mathrm{~F}_{254}$; catalog no. 5715; Merck \& Co., Inc.) developed with an $n$-hexane-ethyl ether (8:2) solvent system, and by mass spectrum data. In addition, a peak of $\mathrm{C}_{21: 0}$ acid was detected; this acid was thought to be cyclopropane acid because of its retention time, its ability to produce a peak after hydrogenation, and its mass spectrum, which was almost the same as that of $\mathrm{C}_{21: 1}$ acid $(5,7)$. A few fatty acids were not identified, but the cellular fatty acid compositions of all of the strains were essentially the same.

Cytochrome systems. Type $b$ and $c$ cytochromes were found in cell-free extracts of all of the strains. The absorption maxima of the $\alpha, \beta$, and $\gamma$ peaks of both cytochromes are listed in Table 2. The terminal cytochrome of the respiratory chain could not be determined by the procedures used in this study.

Electrophoresis of cell proteins. The electrophoretic patterns of the total soluble proteins of the strains are shown in Fig. 4. All of the strains showed essentially the same pattern, indicating a very close relationship. However, there were differences in the relative mobilities of several proteins (Fig. 4 , arrows), although it was not known to which enzymes these proteins corresponded. The six strains were divided into three groups based on these differences (strains TK-6 ${ }^{\mathrm{T}}$, TK-38, and TK-120; strains TK-F and TK-H; strain TK-G). The relative mobility of malate dehydrogenase was the same for all six strains, and the relative mobility of isocitrate dehydrogenase was the same for five strains (the relative mobility of strain TK-G isocitrate dehydrogenase was lower). In the case of glucose-6-phosphate isomerase, strains TK- $6^{\mathrm{T}}$, TK -38 , and TK-120 each had three bands at the same positions. Strains TK-F and TK-H also had three protein bands in common, but the relative mobilities of the top bands were lower than those of the strain TK $-6^{\mathrm{T}}$, TK-38, and TK120 bands. Strain TK-G produced only two bands. 

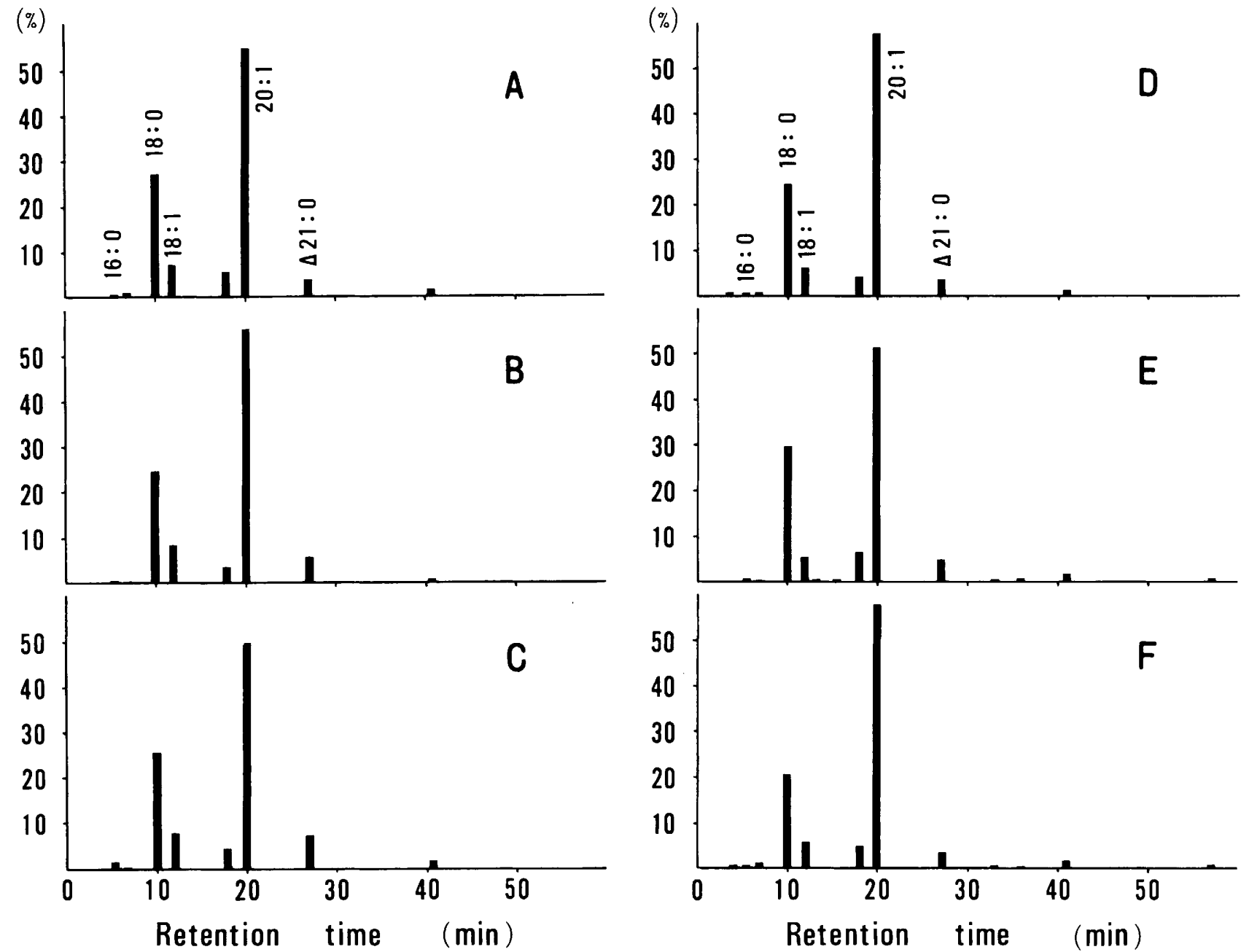

FIG. 3. Fatty acid compositions of $\boldsymbol{H}$. thermophilus strains. (A) Strain TK-6 ${ }^{\mathrm{T}}$. (B) Strain TK-38. (C) Strain TK-120. (D) Strain TK-F. (E) Strain TK-G. (F) Strain TK-H.

\section{DISCUSSION}

Strains TK-6 ${ }^{\mathrm{T}}$, TK-38, TK-120, TK-F, TK-G, and TK-H are extremely thermophilic, aerobic, hydrogen-oxidizing bacteria. Previously, only one extremely thermophilic, hydrogen-oxidizing bacterial species, Bacillus schlegelii, has been described $(2,24)$. The morphological and physiological data for our isolates show that these strains are quite different not only from $B$. schlegelii but also from the other strains of aerobic, hydrogen-oxidizing bacteria described previously. In particular, the obligately chemolithotrophic nature of the strains is the most conspicuous difference from the other hydrogen-oxidizing bacteria. We tried to grow the strains heterotrophically under various conditions but failed. In addition, we observed inhibitory effects of organic compounds on autotrophic growth similar to the effects observed with other obligately autotrophic bacteria, such as thiobacilli (18).

The hydrogen-oxidizing bacteria have been considered to be a physiological group that contains no obligate chemolithotrophs, in contrast to the other chemolithotrophic bacterial groups. Our identification of obligately chemolithotrophic, hydrogen-oxidizing bacteria suggests that the concept described above should be revised and that it may be possible to isolate various kinds of hydrogen-oxidizing bacteria from diverse biological environments.

TABLE 2. Cytochromes of $H$. thermophilus strains

\begin{tabular}{|c|c|c|c|c|c|c|c|}
\hline \multirow{2}{*}{ Cytochrome type } & \multirow{2}{*}{ Absorption band } & \multicolumn{6}{|c|}{ Absorption maxima $(\mathrm{nm})$ for strain: } \\
\hline & & $\mathrm{TK}-6^{\mathrm{T}}$ & TK-38 & TK-120 & TK-F & TK-G & TK-H \\
\hline \multirow[t]{3}{*}{$b$} & $\alpha$ & $560-561$ & 560 & 560 & 561 & $561-562$ & $560-561$ \\
\hline & $\beta$ & 530 & 531 & 531 & $531-532$ & 531 & 530 \\
\hline & $\gamma$ & 429 & 429 & 429 & 430 & $429-430$ & 429 \\
\hline \multirow[t]{3}{*}{$c$} & $\alpha$ & 552 & 552 & $551-552$ & 552 & 552 & $552-553$ \\
\hline & $\beta$ & 521 & 521 & $521-522$ & 521 & 521 & 521 \\
\hline & $\gamma$ & 421 & 418 & 418 & 418 & 418 & 418 \\
\hline
\end{tabular}




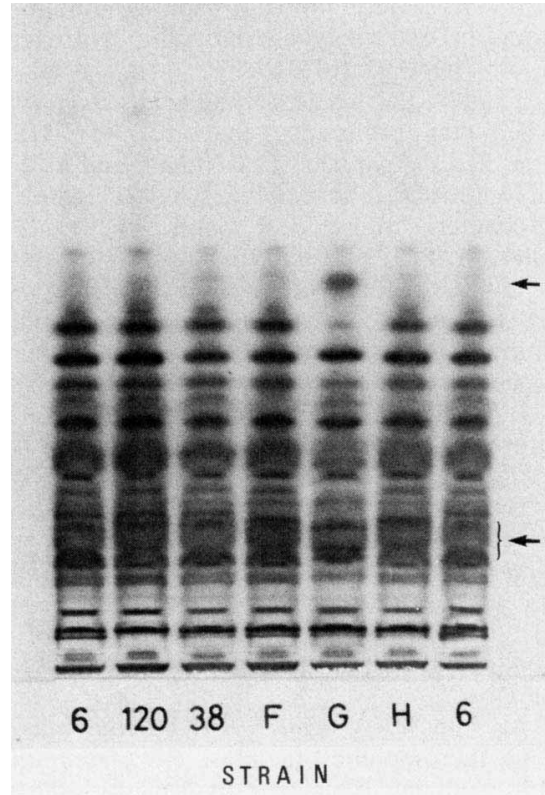

FIG. 4. Electrophoretic patterns of total cell proteins. The arrows indicate the areas where strain-specific patterns were observed.

Conventional taxonomic techniques could not provide valuable data because the strains did not grow on heterotrophic media. Therefore, DNA base composition, cellular fatty acid composition, cytochrome systems, and electrophoresis of cell proteins were investigated.

The guanine-plus-cytosine contents of the DNAs of our strains were the lowest values among the hydrogen-oxidizing bacteria investigated so far (both gram-negative and grampositive bacteria). All hydrogen-oxidizing bacteria described previously have more than $60 \mathrm{~mol} \%$ guanine plus cytosine. $B$. schlegelii, which is gram variable, has 67 to $68 \mathrm{~mol} \%$ guanine plus cytosine, a much higher DNA base composition value than the values obtained for our strains. These results suggest that our strains are taxonomically distant from the other hydrogen-oxidizing bacteria.

Cellular fatty acid composition is being studied in many taxonomic groups of bacteria and is now widely accepted as a useful taxonomic criterion for bacteria (19). All of our strains have $\mathrm{C}_{18: 0}$ and $\mathrm{C}_{20: 1}$ acids as the major fatty acids. No bacterial group possessing such a fatty acid pattern has been reported previously. This means that our strains represent a physiological group which is quite different from the other bacterial groups whose fatty acid compositions have been examined. Many bacterial groups have fatty acid patterns that are comprised mainly of $\mathrm{C}_{16}$ and $\mathrm{C}_{18}$ acids $(15,17,22$, 27). Compared with these bacteria, our strains have a unique cellular fatty acid composition, which consists of acids with chains that are two carbon atoms longer. Enzymatic studies of fatty acid synthesis are interesting physiologically and evolutionarily.

All of our isolates possessed type $b$ and $c$ cytochromes. Type $b$ and $c$ cytochromes have been found in mesophilic, gram-negative, hydrogen-oxidizing bacteria belonging to the genera Pseudomonas (4) and Alcaligenes (4). This coincidence is very interesting, but we will not be able to explain it until the primary electron acceptor from hydrogen and the energy-generating mechanism from hydrogen are made clear. Identification of the terminal cytochrome of the respiratory chain is also an interesting subject.

Quinone systems are regarded as valid criteria in bacterial taxonomy $(8,28)$, as well as cellular fatty acid composition. We have reported previously that all of our strains have a new sulfur-containing quinone (2-methylthio-3-VI, VII-tetrahydromultiprenyl ${ }^{7}-1,4$-naphthoquinone) (16). This quinone has quite a different structure from caldariellaquinone (10), which was isolated from the acidophilic thermophile Caldariella acidophila and is the only sulfur-containing quinone known to date.

The electrophoretic patterns of the cell proteins suggest that the group of strains isolated from Izu (strains TK $-6^{\mathrm{T}}$, TK-38, and TK-120) was a little different from the strains isolated from Kyushu (strains TK-F, TK-H, and TK-G). However, this difference is thought to be characteristic at the strain level. Distinction among the strains within the groups was difficult, except for differentiation of strain TK-G from strains TK-F and TK-H. Strain TK-G could be distinguished from strains TK-F and TK-H by growth characteristics, although it was isolated from the same place as strain TK-F. These facts suggest that bacteria similar to our isolates are widespread in natural thermal environments.

Our results indicate that our strains form a new bacterial group which is distinct from any other bacterial group. Therefore, we propose to place these strains in a new genus and species, Hydrogenobacter thermophilus gen. nov., sp. nov. A description of the new genus and species is given below; the description of the species is the same as that for the genus, since $H$. thermophilus is the only species in the genus.

Hydrogenobacter thermophilus gen. nov., sp. nov. (Hy. dro.ge.no.bac'ter. Gr.n. hydro water; Gr.n. genus offspring; M.L.neut.n. hydrogenum hydrogen, that which produces water; M.L.n. bacter masculine equivalent of Gr.neut.n. bacterium a rod; M.L.masc.n. hydrogenobacter hydrogen rod. ther.mo'phi.lus. Gr.n. therme heat; Gr.adj. philus loving; M.L. masc.adj. thermophilus heat loving) cells are gram-negative, aerobic rods that are 0.3 to 0.5 by 2.0 to $3.0 \mu \mathrm{m}$. Occurs singly or in pairs. Nonsporulating. Motile strains have not been found. Respiratory metabolism, using molecular oxygen as the electron acceptor. Chemolithotrophic, using molecular hydrogen as the electron donor and carbon dioxide as the carbon source. Chemoorganotrophic growth has not been found. Ammonium and nitrate salts are utilized as nitrogen sources. Growth factors are not required. Temperature optimum, 70 to $75^{\circ} \mathrm{C}$. No growth at 37 or $80^{\circ} \mathrm{C}$

The guanine-plus-cytosine content of the DNA ranges from 43.5 to $43.9 \mathrm{~mol} \%$.

A straight-chain saturated $\mathrm{C}_{18: 0}$ acid and a straight-chain unsaturated $C_{20: 1}$ acid are the major components of the cellular fatty acids.

2-Methylthio-3-VI, VII-tetrahydromultiprenyl ${ }^{7}$-1,4-naphthoquinone (methionaquinone) is the major component of the quinone system.

Distribution: isolated from hot water-containing soils at hot springs in Japan.

Type strain: Hydrogenobacter thermophilus strain TK-6 $(=$ IAM 12695)

\section{ACKNOWLEDGMENTS}

We are grateful to Kazuo Komagata and his colleagues at the Institute of Applied Microbiology, University of Tokyo, for their valuable technical aid and discussions. 


\section{LITERATURE CITED}

1. Andersson, B. Å., and R. T. Holman. 1974. Pyrrolidides for mass spectrometric determination of the position of the double bond in monounsaturated fatty acids. Lipids 9:185-190.

2. Aragno, M. 1978. Enrichment, isolation and preliminary characterization of a thermophilic, endospore-forming hydrogen bacterium. FEMS Microbiol. Lett. 3:13-15.

3. Beatrice, M. C., and J. B. Chappell. 1979. The respiratory chain of Hydrogenomonas H-16. Biochem. J. 178:15-22.

4. Bernard, U., I. Probst, and H. G. Schlegel. 1974. The cytochromes of some hydrogen bacteria. Arch. Microbiol. 5:109210.

5. Brian, B. L., and E. W. Gardner. 1968. A simple procedure for detecting the presence of cyclopropane fatty acids in bacterial lipids. Appl. Microbiol. 16:549-552.

6. Brock, T. D., and H. Freeze. 1969. Thermus aquaticus gen. n. and sp. n., a non-sporulating extreme thermophile. J. Bacteriol. 98:289-297.

7. Christie, W. W., and R. T. Holman. 1966. Mass spectrometry of lipids. I. Cyclopropane fatty acid esters. Lipids 1:176-182.

8. Collins, M. D., and D. Jones. 1981. Distribution of isoprenoid quinone structural types in bacteria and their taxonomic implications. Microbiol. Rev. 45:316-354.

9. Davis, B. J. 1964. Disc electrophoresis. II. Method and application to human serum proteins. Ann. N.Y. Acad. Sci. 121:404427.

10. De Rosa, M., S. De Rosa, A. Gambacorta, and L. Minale. 1977. Caldariellaquinone, a unique benzo[b]thiophen-4,7-quinone from Caldariella acidophila, an extremely thermophilic and acidophilic bacterium. J. Chem. Soc. Perkin Trans. I, p. 653657.

11. Doetsch, R. N. 1981. Determinative methods of light microscopy, p. 26. In Manual of methods for general bacteriology. American Society for Microbiology, Washington, D.C.

12. Doetsch, R. N. 1981. Determinative methods of light microscopy, p. 28. In Manual of methods for general bacteriology. American Society for Microbiology, Washington, D.C.

13. Emnova, E. E., and G. A. Zavarzin. 1977. Characteristics of thermophilic hydrogen bacteria: Hydrogenomonas thermophilus. Mikrobiologiya 46:405-408.

14. Goto, E., T. Kodama, and Y. Minoda. 1978. Growth and taxonomy of thermophilic hydrogen bacteria. Agric. Biol. Chem. 42:1305-1308.

15. Ikemoto, S., H. Kuraishi, K. Komagata, R. Azuma, T. Suto, and H. Murooka. 1978. Cellular fatty acid composition in Pseudomonas species. J. Gen. Appl. Microbiol. 24:199-213.

16. Ishii, M., T. Kawasumi, Y. Igarashi, T. Kodama, and Y.
Minoda. 1983. 2-Methylthio-1,4-naphthoquinone, a new quinone from an extremely thermophilic hydrogen bacterium. Agric. Biol. Chem. 47:167-169.

17. Kaneda, T. 1977. Fatty acids of the genus Bacillus: an example of branched-chain preference. Bacteriol. Rev. 41:391-418.

18. Kawasumi, T., Y. Igarashi, T. Kodama, and Y. Minoda. 1980. Isolation of strictly thermophilic and obligately autotrophic hydrogen bacteria. Agric. Biol. Chem. 44:1985-1986.

19. Lechevalier, M. P. 1977. Lipids in bacterial taxonomy-a taxonomist's view. Crit. Rev. Microbiol. 5:109-210.

20. Marmur, J., and P. Doty. 1962. Determination of the base composition of deoxyribonucleic acid from its thermal denaturation temperature. J. Mol. Biol. 5:109-118.

21. McGee, J. M., L. R. Brown, and R. G. Tischer. 1967. A hightemperature, hydrogen-oxidizing bacterium-Hydrogenomonas thermophilus, n. sp. Nature (London) 214:715-716.

22. Oyaizu, H., and K. Komagata. 1981. Chemotaxonomic and phenotypic characterization of the strains of species in the Flavobacterium-Cytophaga complex. J. Gen. Appl. Microbiol. 27:57-107.

23. Saito, H., and K. Miura. 1963. Preparation of transforming deoxyribonucleic acid by phenol treatment. Biochim. Biophys. Acta 72:619-629.

24. Schenk, A., and M. Aragno. 1979. Bacillus schlegelii, a new species of thermophilic, facultatively chemolithoautotrophic bacterium oxidizing molecular hydrogen. J. Gen. Microbiol. 115:333-341.

25. Shaw, C. R., and M. Siciliano. 1976. Separation and visualization of enzymes on gels, p. 185-209. In I. Smith (ed.), Chromatographic and electrophoretic techniques, 4th ed., vol. 2. William Heinemann Medical Books Ltd., London.

26. Thomas, P. E., D. Ryan, and W. Levin. 1976. An improved staining procedure for the detection of the peroxidase activity of cytochrome P-450 on sodium dodecyl sulfate polyacrylamide gels. Anal. Biochem. 75:168-176.

27. Uchida, K., and K. Mogi. 1972. Cellular fatty acid spectra of Pediococcus species in relation to their taxonomy. J. Gen. Appl. Microbiol. 18:109-129.

28. Watanuki, M., and K. Aida. 1972. Significance of quinones in the classification of bacteria. J. Gen. Appl. Microbiol. 18:469472.

29. Zeikus, J. G., and R. S. Wolfe. 1972. Methanobacterium thermoautotrophicus sp. n., an anaerobic, autotrophic, extreme thermophile. J. Bacteriol. 109:707-713.

30. Zeikus, J. G., and R. S. Wolfe. 1973. Fine structure of Methanobacterium thermoautotrophicum: effect of growth temperature on morphology and ultrastructure. J. Bacteriol. 113:461-467. 